\title{
CONCEPT OF SIMULACRA OF VIRTUAL-ONLINE CULTURE OF INFORMATIONAL SOCIETY: CONCEPTUAL SURVEY OF POSTEMODERNISTS
}

\author{
(C) KYRYCHENKO, MYKOLA \\ SHEI «University of Educational Management»of NAES of Ukraine, (Kyiv, Ukraine) \\ E-mail: kmumo@i.ua, ORCID 0000-0003-1756-9140
}

\begin{abstract}
The urgency of the research is that the simulacra of the virtual-online culture of the information society and the conditions for its formation are analyzed. The term "simulacrum" by J. Baudrillard is related to the virtual-online culture of the information society, because a person uses substitutes, copies of things, and not their originals. Setting objectives. This problem is caused by the fact that today the personality is formed in an artificially created virtual world that distorts the personality and forms its torn and inappropriate image. This type of society as a virtual-online one needs its interpretation and analysis of a new conceptual-categorical apparatus. Analysis of recent research and publications. These are works by J. Baudrillard "Simulacra and simulations" (1981), as well as R. Simmel, R. Bart, R. Deborah, G. Bataille, G. Lacan, M. McLuhan, M. Foucault, G. Deleuzae, J. Derrida.The questions of the philosophy of postmodernism and the theory of simulacra of J. Baudrillard are considered in the works of such researchers: A. Gritsanov, $N$. Katsuk, A. Dyakov, N. Zinchenko, N. Mankovskaya, O. Pechenkina, O. Scalatska, V. Ferroni and others. The question of the simulacrum is considered by J. Baudrillard in a number of works: "Symbolic Exchange and Death", "Seduction", "Simulacra and Simulation", "Transparency of Evil" and others.The selection of unexplored parts of the general problem is the conceptualization of the concept of "simulacrum" and its discovery in the virtual-online information society. The basis of the research is the conceptualization of the basic patterns of simulacra and the virtual-online culture of the information society, which is a scientific novelty. Setting the objective - the usage of approaches, in particular, structural-synergistic and practical synergetic methodology that makes it possible to analyze the simulacra of postmodern as complex constuctions. Presenting main material. The analysis of formation and development of online-virtual culture of personality which uses simulacra; the definition of "simulacrum" is presented; an analysis was made of the fact that the game constituent has become a dominant component of the modern virtual world, and the game itself became a marker of the postmodern society with the performing "I"-game in the middle; the definition of "online virtual culture" is given in the context of which "I" is implemented; the network society is shown as a new type of culture (subculture) of virtual reality. Conclusions - the simulacra of the virtual-online culture of the information society in the conceptual survey of postmodernists has been formed.
\end{abstract}

Key words: simulacrum, virtual-online culture, information society, postmodern, game component of the virtual world, game "I".

General presentation of the problem and its connection with important scientific or practical tasks. The urgency of the study of simulacra of virtual-online culture in the context of practical synergetic methodology is gaining weight. The concept of "simulacrum" (derived from Lat. "Simulacrum, Idola, Phantasma") [1, p.123127]. This problem is caused by the fact that today the personality is formed in an artificially created virtual world that distorts the personality and forms its torn and inappropriate image. In connection with this, the problem of identifying simulacra of the virtual-online culture of the individual depends on many factors - education, personal development, cultural markers. As a result of inadequate socialization and then 
re-socialization, a person loses humanity, humanism, one's true nature, culture, society as well asoneself and moves to a different world - virtual one. This anthropological crisis, deeply penetrated into the present, contributes to thisas well as the loss of confidence in the future, which is difficult to predict; lack of a law-governed state, since there is no protection of the ordinary person; the victory of the "one-dimension person", whobecomes the subject and the object of virtual reality; the growing dependence of man from machine (Internet), the decline of morality, culture, spirituality; creation of artificial needs; the escalation of violence and terrorism in permanently changing information space [9].

The analysis of recent researches and publications initiating the solution of the problem as presented by the authors

Recent research on the simulacra of virtual-online culture suggests that in the era of total turnover, the humanistic potential of modern culture, science, and education is devalued. In the article the author tries to criticize the reception of conceptual ideas of simulacra (the term of the philosophy of postmodernism) of virtual-online culture as complex social and cultural phenomena aimed at construction of certain events. The term "simulacrum" is the prototype of Plato's term "copy of copies". In particular, considerable attention is paid to the analysis of papers that consider the phenomenon of simulacra, constructed in the act of a semioisis and have no other form of being, except perceptively symboolic [2]. These are the works by J. Baudrillard "Simulacra and simulations" (1981), as well as R. Simmel, R. Bart, R. Deborah, G. Bataille, G. Lacan, M. McLuhan, M. Foucault, G. Deleuzae, J. Derrida. The questions of the philosophy of postmodernism and the theory of simulacra of J. Baudrillard are considered in the works of such researchers: A. Gritsanov, N. Katsuk, A. Dyakov, N. Zinchenko, N. Mankovskaya, O. Pechenkina, O. Scalatska, V. Ferroni and others. The question of the simulacrum is considered by J. Baudrillard in a number of works: "Symbolic Exchange and Death", "Seduction", "Simulacra and Simulation", "Transparency of Evil" and others. In the work "Symbolic Exchange and Death," he describes three orders of simulacra, and in the book "Simulacra and Simulation" he shows the connection of simulacra with the imaginary and characterizes their influence on reality. "Simulacra and Simulation"includes almost two dozen short essays. The first is the "Simulacra Process", where the author deploys the basic theoretical constructions. Next goes a series of illustrative essays where various phenomena of the today postmodern era are analyzed: science fiction, holograms, clones, advertising, the Holocaust, the media, where he states hopelessness of the modern world. The term "simulacrum" was introduced into the circulation of postmodernism by Bataille, interpreted by Klosovsky, Kojeve, Baudrillard, Deleuzae, and Jameson. For the latter one simulacrum is "an exact copy, the original of which never existed".

All this suggests that simulacra are used to denote extranotionalmeans and to capture transgressive experiences. Simulacraserve as a special communication experience based on reconstruction of verbal partners in the course of communication using cononative meanings of the statement [4].

Previously unresolved parts of the general problem. Setting objectives

The network-online personality culture generated by virtual space is characterized by uncertainty, decentralization, the need to generate game-likeconstructionof communications and create game context, as the communication is shifted to the game space, generating a virtual person and a virtual online culture. And although virtual world in some cases protects an unprotected virtual person from the absurdity of being, unpredictability, instability, insecurity, chaos of the world, yet virtual reality is precisely what generates this world and cultivates destructive tendencies in human existence [5].

The purpose of the research is to conceptualize the simulacra of the virtualonline culture in the context of identifying the conceptual dominants of postmodernists and to compare the concept of "simulacrum" with the virtual-online personality culture, 
with which there is much in common.

This goal is achieved through a number of tasks:

- to analyze the formation and development of online-virtual culture of the personality who uses simulacrama;

- to define the "simulacrum";

- to analyze the fact that the game constituent has become a dominant component of the modern virtual world, and the game itself became a marker of the postmodern society with the performing "I"game in the middle;

- to define the "online-virtual culture" being the context where "I" is materialized;

- to discover network society as a new type of organizational structure, being also culture-subculture of virtual reality.

The object of research is the concept of simulacra as a complex social and cultural phenomenon.

The subject of research is the virtualonline culture in the context of discovering conceptual dimensions of post-modernists and the deployment of simulacra.

The methodology is a structural synergistic and practical synergetic methodology that makes it possible to analyze the postmodern simulations as complex constructions of being.

\section{Discussion of the problem}

The formation and development of a network-online culture of personality in the space of virtual reality should be defined as the victory of the destructive nature of man, described by S. Freud, E. Fromm. The society is responsible for destruction, it moves a person into the world of virtual reality associated with the emergence of a new phenomenon of virtual civilization in the twenty-first century $[16 ; 17]$.

Under the simulacra Baudrillard understands the images that absorb the personality and supplant it in the world of non-existent, invented reality. Simulacra reproduce and broadcast meanings that are inadequate to events, facts that are not subject to unambiguous interpretation. The simulacra, according to the author, arise only at a certain stage of cultural development. In his book "Symbolic Exchange and Death" J. Baudrillard offers a historical scheme of "three orders" of simulacra, changing each other in the New European civilization. Each sign here represents a reflection of some substantive reality: the simulacra of the Renaissance, the industrial revolution, and the modern virtual society .

The virtual society has relied on the mass-tought individual, whose imagelacks creative element, and as a result, a person acts as a mindless consumer of mass products of the Internet and transforms the established traditional hierarchy of values, destruction of which takes place in all spheres of human life. The game constituent has become a dominant component of the modern virtual world, and the game itself became a marker of the postmodern society with the performing "I"-game in the middle. Today, the role of the game is relevant both in the modern process of identification of the individual, in the development of social communications, in the transformation of virtual reality, and in the establishment of the polyontological world, and in each sphere of human life in the form of the implementation of various technologies.

Previous taboos of traditional society have been rejected, leading to emerging of space for game interaction, which transformed life itself into a game in the "carnival way of life" of virtuality. In a virtual world, personality is governed by disharmony, asymmetry, assonance, absurd, andational, incomplete, torn "I". It is the implementation of social communications for the mentality of a person of the postmodern (virtual) world that is defined as rhizomatic one (G. Deleuzae, F. Guattari), ironiness, fluidity, uncertainty. According to Baudrillard, such a person does not deal with things, but with "simulacra, masks, copies, copies of copies".

We do not analyze the simulacra of the first and second order (the periods of the Renaissance and the industrial revolution)defined byJ. Baudrillard, and we proceed to the simulacra of the third order, which are related to the theme of our research. Third order simulacraare no longer a fake of the original, as in the simulacra of the first order, but not pure seriality, as in second-order simulacra. Here all forms are 
displayed only when correlating with the model. Simulation is more fundamental than in serial reproduction, here the interchangeability of characters is more fundamental. Space is no longer linear or measurable, it infinitely reproduces the same signals. As J. Baudrillard writes, models interfere with everyday life, our way of communicating with the world comes close to reading, to selective decoding, to mass media game and questionnairesof a question-answer pattern. He believes that the simulation processes cover the whole world of culture and human relationships.

The game as a phenomenon of social relations of virtuality gives it the character of fragmentarity, superficiality, inconsistency, remoteness from others, provides the context where it is easier for a person to protect his inner world with his own rules of the game, which makes the process of identifying a person with this world fluid, unstable, unconscious, and it easily yields to transformations and metamorphoses in the informational being $[9 ; 10 ; 11 ; 12]$. The very existence of a man in the virtual world, manifested through selffulfillment, self-presentation, selfidentification, has a game form, and it is impossible to imagine a person outside this gaming element into which it is drawn. Under the influence of the virtual element game, the integration of existential and informational fields is transformed, a person loses the path in searching his immanent forces, self-identification as a process of finding a oneself is lost.

The search for a personal "self" requires a rationale for the problem of correlation of personal, individual and personnified, on one hand, as well as social, collective and typical, on the other, which requires a personal search for one's identity and selfidentity [6]. Baudrillard proves the ambiguity of the existing social reality and explains the simulacra as a result of the simulation process ("the generation of a hyperreal"), "with the help of real models that do not have their own origins and reality" [7].
So, let's define the network-online culture of personality. It represents an integrative cultural form that is characterized by a self-organizing element and a functional diversity. On one hand, it is a new form of contactless information interaction of the user with online environment, a computer system that provides certain visual and sound effects. On the other hand, virtual culture as an information resource possesses means of mass communication and promotes cultural exchange and communication. The virtual-online world is more flexible, mobile, facilitating personality transformation, it has a simplified nature of mobility, wherea social status, a financial status, etc. often is not important; it has an emotional environment with an easier communication system, which often allows you to confront everyday life, it has more freedom and creativity. The virtual-online culture is defined as an attempt to implement a transcendental, ideal and absolute beginning in the present being; as an experience of implementing the direct selfrealization of the individual, constructed in figurative-gaming models of the real cultural activity of the subject [8].

Intensification of communication links increase in the process of cybersocialization, which is a process of personality development in the context of the development of cultural outlines of information society, representing a qualitative context that forms the technological relations able to transform the very specificity of human existence. Society as a system of communications represents the image of networks, woven with a large number of networks, that symbolize communicative relations, and knots promote communication as a reflexive reality of being. They represent ways of translating information of various sociological groups and social relationships that absorb a person [15].

The virtualization of society leads to the virtualization of people's lives, which contributes to the emergence of a culture of "real virtuality," capable of subjugating people within the material framework - the communicative network. In modern 
information multiprocesses-structures of the development of his existence, a person explodes various levels of communication with various actors, both real and virtuous, shaping his own world in dialogue with numerous groups and associations. Hence, the network society is not only a new type of organizational structure, but also a culturesubculture of virtual reality [14].

Through the mediation of the communication network as a component of the unit of the communication macromodel of the world, social relations evolve into technological virtual reality. The individual tries to replace the real sociocultural life with the images of the new world with the help of virtual simulations [18].

The new virtual world, formed by new technologies, new social structures and a new culture, guides the individual to a new perception of the world, whose signs require the decoding of the meaning encoded. In the course of scientific and technological progress, information virtual reality stimulates the ever-increasing intellectualization of society and serves as a factor for optimizing professionalization, intensification, efficiency improvement, etc. The basic principles of this society are electronization, informatization, computerization, mediatization, virtualization, with the mechanism where the substitution of real images and the virtualization of society intensifies human life. As a result of all processes virtualization as a determinant factor acts as an imperative, the institutional form of which is simulated, since in this reality images are created and transmitted and virtualized and contribute to the fact that society does not disappear, but is redefined [19].

In the context of redefining society, values as the most important component of the culture of the information society are redefined. The main value of the information society is a person whose high projections of development are only a prerequisite for representing his ideals, free creative selffullfilment. To help a person survive in the difficult realities of the new information society there are high information values that require the provision of meaningful information that meets a number of requirements, namely openness (availability), reliability, completeness, efficiency, cost effectiveness, consistency, and rational form of information provision. Human values are manifested in the creative acts of its self-actualization, which affirms the value meaning that cultivates the individual [20].

The scientific novelty and practical significance of the problem under research is theurgent need to study all the processes taking place in the virtual world in order to form the ideal image of a modern man, rich in traditions, cultural values, spirituality, and to form directions for overcoming the contradictions of the virtual world that interfere with holistic formation of a person. In the "society of play", as S. Kutcepal notes, "subjectivity is replaced by the infinite variety of simulacra masks to be studied" [15].

Let's turn to the updating of the notionmeaning of "simulacrum", which can be done only under certain procedures. A simulacrum can be endowed with meaning only if certain of its associative and cononational aspects, implicitly incorporated by the addressee, are updated and copied in the perception of the addressee. "Conceptual language" determines the identity of existence with being, thus deforming being as being escaping from any meanings. The fundamental characteristics of any simulacrum is its incompatibility with reality, acting in Bataille's "quasisimulacra", or "simulacra of simulacra". Thus, communications carried out through the simulacra [p. 901] do not pretend to be constant, but a moment that passes fast. Simulacra play the role of a semantic focus, attracting integration of associative rows, and then the simulacrum tries to penetrate into the consciousness of the Other. The creation of meaning in this context takes place as the self-organization of release from the subject, which is called "the death of the subject" $[20 ; 21 ; 22 ; 23 ; 24 ; 25]$.

At its best, the theory of J. Baudrillard is presented in the book "Symbolic Exchange and Death" (1976). Actualization of the 
simulacrum value can only be reached in procedures. A simulacrum can be endowed with meaning only if some of its associative and cononational aspects, implicitly incorporated in them by the addressee, are updated and copied in the perception of the addressee [30]. "Conceptual language" determines the identity of existence with being, thus deforming being as being escaping from any meanings. The fundamental characteristics of any simulacrum is its incompatibility with the reality, acting in Bataille's "quasisimulacra," or "simulacra of simulacra" [7].

Thus, the communication, carried out through the simulacra, suggests that the simulations do not pretend to be constant, but it is a moment that passes fast. The reality is not primary, but it is the signs. In the conceptual sense of postmodernists, all the usual reality of things is replaced by the reality of signs. We have to talk about two realities: if things are considered a reality, the signs are hyperreality. Signs act as values, that is, they are conceptual [26].

Consequently, J. Baudrillard deserves a high appreciation for his desire to give the theory of the entire social universe. For such an action, few have dared before him. He acutely raised the question of distinguishing between genuine and fake. Eliminating the difference between people, things and signs,
J. Baudrillard obviously extinguished their peculiarity.

Thus, let us note that this creates the preconditions for penetration into the sphere of virtuality, as well as the search for strategies of civilization development of human socialization. The latter actualizes the study of the image of the virtual person and its characteristics, presented today by the new discipline "virtualism", which includes the analysis of information and communication relations and the place and role of a person who perceives the virtual reality and is a virtual person himself. Therefore it is necessary:

Identify the key determinants of spirituality that must confront the values of the virtual world and the virtual person and form the adaptive abilities of the person to the information world and manifest the high spirituality of the information culture.

To uncover the need for the formation of a new consciousness, worldview, culture of the information society and to introduce in the educational process the study of "virtuality" and "informationology" as new disciplines that can sensitize the problems revealing the place and role of a person in the virtual world and simulacra, which "enchanted" the world of a virtual reality person.

\section{СПИСОК ВИКОРИСТАНИХ ДЖЕРЕЛ}

1. Бодрийяр Ж. Симулякры и симуляции // Философия эпохи постмодерна: сб. переводов и рефератов. Минск, 2006. С. 123-127.

2. Бодрийяр Ж. Система вещей : пер. с фр. С. Зеникина. М.: Рудомино, 2001. 218 с.

3. Бодрийяр Ж. Общество потребления. Его мифы и структуры: пер. с фр. Е.А.Самарской. М.: Республика; Культурная революция, 2006. 269 с. (Мыслители ХХ века).

4. Бодрийяр Ж. Символический обмен и смерть; [пер. с фр. С. Н. Зенкин]. М. : «Добросвет», 2000. 387 с.

5. Воронкова В. Г. Концепции взаимосвязи человека, сознания, разума в контексте виртуально-информационного пространства // Философия и космология. 2013.

6. Грицанов А.А. Жан Бодрийяр / А.А. Грицанов, Н.Л. Кацук. Мн. : Книжный Дом, 2008. $256 \mathrm{c}$.

7. Дьяков А. В. Жан Бодрийяр: Стратегии «радикального мышления». СПб. : Изд-во С.-Петерб. ун-та, 2008. 357 с.

8. Зінченко Н. О. Теорія симулякра Ж. Бодрійяра: історико-філософський аспект : автореф. дис. на здобуття наук. ступеня канд. філос. наук : спец. 09.00 .05 «сторія філософії» / Н.О. Зінченко. К., 2011. 
9. Інформаційне суспільство в світі та Україні: проблеми становлення та закономірності розвитку: колективна монографія.Запоріжжя: РВВ ЗДІА, 2017. 282 с.

10. Кастельс М. Информационная эпоха: экономика, общество, культура; пер. с англ. О. И. Шкаратана. М. : ГУ ВШЭ, 2000. 607 с.

11. Кастельс М. Пути к информационному обществу: структура занятости в семи главных индустриальных странах, 1920-1990 гг. // Междунар. обзор труда. М., 1995. Т. 133, № 1 / 3. С. 52 - 79.

12. Кастельс М. Информационное общество и государство благосостояния: Финская модель; пер. с англ. А. Калинина, Ю. Подороги. М. : Логос, 2002. 219 с.

13. Кастельс М. Галактика Интернет: размышления об Интернете, бизнесе и обществе; пер. с англ. А.Матвеева, под ред. В.Харитонова. Екатеринбург: У-Фактория, $2004.327 \mathrm{c}$.

14. Кириченко М. О. Інформатизація як фактор оптимізації ідеології інформаційного суспільства та забезпечення його сталого розвитку. Scientific Journal «ScienceRise : Pedagogical Education». Харків. № 1(9) 2017. С. 46-50.

15. Куцепал С. В. Ідентичність модерна і постмодерна // Філософські обрії. Науково-теоретичний журнал Інституту філософії імені Г. С. Сковороди НАН України та Полтавського національного педагогічного університету імені $В$. Г. Короленка. Вип. 17. К.: Полтава, 2007. С. 3-15.

16. Лазаревич А. А. Глобальное коммуникационное общество. Минск : Белорус. наука, 2008. $350 \mathrm{c}$.

17. Лазаревич А. А. Становление информационного общества: коммуникационноэпистемологические и культурно-цивилизационные основания; науч. ред. И. Я. Левяш. Минск : Беларуская навука, 2015. 537 с.

18. Максименюк М. Ю., Нікітенко, В. О. Формування парадигми інформаційнокомунікативного суспільства як різновиду складної соціальної системи і взаємодії. Гуманітарний вісник Запорізької державної інженерної академії. Запоріжжя. 2016. Вип. 66. С. 266-278.

19. Мельник В. В. Полікультурність в контексті глобалізації: соціальнофілософський аналіз // Гуманітарний вісник Запорізької державної інженерної академї. 2005. Вип.22. С.217-229.

20. Маньковская Н .Б. Эстетика постмодернизма. СПб. : Алетейя, 2000. 347 с.

21. Нікітенко В. О. Геокультурні цінності в умовах сучасного світового розвитку : соціально-філософський вимір // Гуманітарний вісник Запорізької державної інженерної академії. Запоріжжя. 2013. Вип. 54. С. 266-280.

22. Переломова О. С. Інтертекстуальність як системотвірна текстово-дискурсивна категорія // Гуманітарний вісник Запорізької державної інженерної академії. 2008. Вип. 34. С.87-95.

23. Печенкина О. А. Божественная ирреферентность образов в философии симулякров Жана Бодрийяра [Електронный ресурс] - Режим доступа : http://www.simulacrum.h16.ru/files/text/refer.pdf

24. Печенкина О. А. Этика симулякров Жана Бодрийяра (анализ постмодернистской рецепции этического). Тула : Тульский полиграфист, 2011. 204 с.

25. Феррони В. В. Теория «симулякров» Ж. Бодрийяра: «Ностальгия по настоящему» / В.В. Феррони // Вестник Воронежского государственного университета. Серия. Гуманитарные науки. 2001. № 2.

26. Хлєбнікова А. А. Становлення і розвиток інформаційного суспільства в умовах глобалізації: теоретико-методологічний контекст // Гілея: науковий вісник. 2015. Вип. 92. C. 170-174. 


\section{REFERENCES}

1. Baudrillard, J. (2006). Simulacra and simulation //Post-modern Philosophy: sat. translations and abstracts. Minsk. 123-127 [in Russian].

2. Baudrillard, J. (2001). The System of Objects: transl. from Fr. byS. Zenikina. M.: Rudomino. 218 s.[in Russian].

3. Baudrillard, J. (2006). Consumer society. His myths and structures: Lane. with Fr. E.a. Samara: Republic; The cultural revolution.269 s. (Thinkers of the twentieth century) [in Russian].

4. Baudrillard, J. (2000). Symbolic Exchange and death; [translation from French by s. h. Zenkin]. M.: «Dobrosvet». 387 s.[in Russian].

5. Voronkova, V.G. (2013). Concept of relationship between human consciousness, mind in the context of virtual information space // Philosophy and cosmology [in Ukrainian].

6. Gricanov, A. A. (2008). Jean Baudrillard /A. Gricanov, N. Katsuk. MN. : Book House. 256 s.[in Russian].

7. Diakov, A. V. (2008). Jean Baudrillard: "radical thinking". Spb. : IZD-vo-Peterb. University. 357 s. [in Russian].

8. Zinchenko, N. O. (2011). Teorija simuljakra J. Bodrijara: is published annuallyfilosofskij facet: katege. Dees. on the zdobuttja of Sciences. stages of Cand. filos. Science: special. 09.00.05 "History filosofii". K. [in Ukrainian].

9. Information society in the world and in Ukraine: problems of establishment and patterns of development: [collective monograph] (2017). Zaporizhzhya: RVV ZDIA. 282 s.[in Ukrainian].

10. Castells, M. (2000). Information era: economy, society and culture; Lane. with engl. O. Shkaratana. M.: HSE. 607 s. [in Russian].

11. Castells, M. (1995). Path to the information society: the structure of employment in the seven major industrialized countries, 1920-1990 Gg. Intern. review of labour. M. Castells m. Internet Galaxy: reflections on the Internet, business and society; Lane. with engl. A. Matveeva, ed. V. Kharitonov of Yekaterinburg:-Hong, 2,004,327 with.. 133, no. 1/3. 52-79. [in Russian].

12. Castells, M. (2002). Information society and the welfare state: the Finnish model; Lane. with engl. A. Kalinin, Y. Podorogi. M.: Logos. 219 s. [in Russian].

13. Castells, M. (2004). Internet Galaxy: reflections on the Internet, business and society; Lane. with engl. A. Matveeva, ed. V. Kharitonov of Yekaterinburg:Hong.327 s.

14. Kirichenko, M. O. (2017). Informatization as a factor of optimizing the ideology of the information society and ensure its sustainable development. Scientific Journal «ScienceRise : Pedagogical Education». Kharkov. № 1 (9). 46-50 [in Ukrainian].

15. Kucepal, S. (2007). Identity of modern and postmodern//Philosophical horizons. The scientific-theoretical Journal of the Institute of philosophy G. S. Skovoroda NAN of Ukraine and Poltava National Pedagogical University named after V. G. Korolenko. Issue. 17. K.: Poltava. 3-15 [in Ukrainian].

16. Lazarevich, A. A. (2008). Global communication society. Minsk: Belarusian. Science. 350 s. [in Russian].

17. Lazarevich, A. A. (2015). Formation of information society: communications and epistemological and cultural-civilizational grounds; researcher. Ed. I. Levjash. Minsk, Belaruskaya navuka. 537 s.[in Russian].

18. Maksimenûk, M.Yu. \& Nikitenko, V. O. (2016). The formation of the paradigm of information-communicative society as a kind of complex social systems and interaction. Humanitarian Bulletin of Zaporizhzhya State Engineering Academy. Zaporizhzhya. Issue. 66. 266-278 [in Ukrainian]. 
19. Melniuk, V. V. (2005). Polikulturnist in the context of globalization: the socialphilosophical analysis//Humanitarian Bulletin of Zaporizhzhya State Engineering Academy. Issue 22. 217-229 [in Ukrainian].

20. Mankovskaya, N. B. (2000). Aesthetics of postmodernism. Spb. : Aletheia. 347 s. [in Russian].

21. Nikitenko, V. O. (2013). Geokulturnì values in today's world development: a sociophilosophical dimension//Humanitarian Bulletin of Zaporizhzhya State Engineering Academy. Zaporizhzhya. Issue. 54. 266-280 [in Ukrainian].

22. Perelomova, O. S. (2008). İntertekstualnìst as sistemotvìrna Word-discourse category//Humanitarian Bulletin of Zaporizhzhya State Engineering Academy. Issue. 34. 8795. [in Ukrainian].

23. Pečenkina O. A. Božestvennaâ irreferentnost образов в философии simulâkrov Жана Bodrijâra[Electronic resource]-access mode : http://www.simulacrum.h16.ru/files/text/refer.pdf [in Russian].

24. Pechenkina, O. A. (2011). Jean Baudrillard's simulacra Ethics (analysis of postmodern ethics reception). Tula: Tula poligrafist. 204 s. [in Russian].

25. Ferroni, V. V. (2001). Theory of "Simulacra" by J. Baudrillard: "Nostalgia for the present/V. Ferroni//Herald of the Voronezh State University. Series. Humanities. № 2 [in Russian].

26. Hlêbnikova, A. A.(2015). Formation and development of the information society in the conditions of globalization: theoretical - methodological context/Gileâ: scientific bulletin. Issue. 92. P. 170-174 [in Ukrainian].

KYRYCHENKO, MYKOLA - Doctor of Philosophy, Professor, Rector Institution «University of Educational Management» of the National Academy of Pedagogical Sciences of Ukraine, Corresponding Member of the Academy of EducationSciences of Ukraine, rector (Kyiv, Ukraine)

E-mail: kmumo@i.ua, ORCID 0000-0003-1756-9140

\section{КОНЦЕПЦІЯ СИМУЛЯКРІВ ВІРТУАЛЬНО-ОНЛАЙНОВОЇ КУЛЬТУРИ ІНФОРМАЦЙНОГО СУСПІЛЬСТВА: КОНЦЕПТУАЛЬНІ ВИМІРИ ПОСТМОДЕРНІСТІВ}

Анотація.Актуальність дослідження в тому, що проаналізованосимулякри віртуальноонлайнової культури інформаиійного суспільства та умови його формування. Термін Ж.Бодрійяра «симулякр» пов'язаний з віртуально-онлайновою культурою інформаційного суспільства, тому що людина користується замінниками, копіями речей, а не їх речами. Постановка завдання. Ця проблема викликана тим, що особистість сьогодні формується у штучно створеному віртуальному світі, що спотворює особистість $і$ формує ї̈ розірваний $i$ нецілісний образ. Даний тип суспільства як віртуально-онлайнового потребує його тлумачення та аналізу нового понятійно-категорійного апарату. Аналіз останніх досліджень $\boldsymbol{i}$ публікацій.Це роботи Ж. Бодрійяра «Симулякри і симуляції» (1981), а також Р. Зіммеля, Р. Барта, Р. Дебора, Ж. Батая, Ж. Лакана, М. Маклюена, М. Фуко, Ж. Дельоза, Ж. Дерріда. Питання філософії постмодернізму та теорії симулякрів Ж. Бодріяра розглядаються у роботах таких дослідників: А. Гриианова, Н. Каиук, А. Дьякова, Н. Зінченко, Н.Маньковської, О. Печенкіної, О.Скалаџької, В. Ферроні та інших. Питання симулякра розглядається Ж. Бодрійяром у низиі робіт: "Символічний обмін і смерть», "Спокуса», «Симулякри і симуляиія», «Прозорість зла» та іниих. Виділення недосліджених частин загальної проблеми кониеептуалізаиія поняття «симулякр» та його виявлення $y$ віртуально-онлайновому інформачійному суспільстві. В основі дослідження - конщептуалізація базових схем симулякрів та віртуально-онлайнової культури інформаиійного суспільства, щцо представляє собою наукову новизну. Постановка завдання - використання підходів, зокремаструктурносинергетичної та практично-синергетичної методології, що дає можливість проналізувати симулякри постмодерну як складні констукції. Виклад основного матеріалу. Здійснено аналіз становлення i розвитку онлайново-віртуальної культури особистості, яка користується симулякрами; представлено визначення «симулякр»; здійснено аналіз того, що ігрова складова стала складовою домінантою сучасного віртуального віту, а сама гра стала маркером 
постмодерністського суспільства, в центрі якого перфомативне, ігрове «Я»; надано визначення «онлайново-віртуальної культури», в контексті якої реалізується «Я»; показано, що являє собою мережевий соиіум як новий вид культури (субкультури) віртуальної реальності. Висновки - сформовано конщещпію симулякрів віртуально-онлайнової культури інформаційного суспільства у концептуальних вимірах постмодерністів.

Ключові слова:симулякр, віртуально-онлайнова культура, інформачійне суспільство, постмодерн, ігрова складова віртуального світу, ігрове «Я»

КИРИЧЕНКО Н. А. - доктор философии, профессор кафедры государственной службы и менеджмента образования, ректор, ГВУЗ «Университет менеджмента образования» НАПН Украины, член-корреспондент Академии наук высшего образования Украины (Киев, Украина)

E-mail: kmumo@i.ua,ORCID 0000-0003-1756-9140

\section{КОНЦЕПЦИЯ СИМУЛЯКРОВ ВИРТУАЛЬНО-ОНЛАЙНОВОЙ КУЛЬТУРЫ ИНФОРМАЦИОННОГО ОБЩЕСТВА: КОНЦЕПТУАЛЬНЫЕ ИЗМЕРЕНИЯ ПОСТМОДЕРНИСТОВ}

Аннотация. Актуальность иследования в том, что проанализированы симулякры виртуально-онлайновой культуры информационного общества и условия их формирования. Термин Ж.Бодрийяра «симулякр» связан с виртуально-онлайновой культурой информационного общества, потому что человек пользуется заменителями, копиями вещей, а не их вещали.Постановка задания. Эта проблема вызвана тем, что личность сегодня формируется в искусственно созданном виртуальном мире, который искажает личность и формирует ее разорванный и нецелостный образ. Данный тип общества как виртуальноонлайнового требует его толкования и анализа нового понятийно-категориального аппарата. Анализ последних исследований и публикаций. Это работы Ж.Бодрийяра «Симулякры и симулячии (1981), а также Р. Зиммеля, Р.Барта, Р. Дебора, Ж.Батая, Ж. Лакана, М. Маклюена, М. Фуко, Ж. Делеза, Ж. Даррида. Вопросы философии постмодернизма и теории симулякров Ж. Бордрийяра рассмотрень в работах таких исследователей: А. Гриианова, Н. Каиук, А. Дьякова, Н. Зинченко, Н. Маньковской, О. Печенкиной, О.Скалачкой, В. Феррони и других. Вопрос симулякра рассматривается Ж. Бодрияйром в ряде работ: «Символический обмен и смерть», "Соблазн», «Симулякры и симуляция», «Прозрачность зла» и других. Выделение неисследованных частей общей проблемы - концептуализация понятия «симулякр» и его выявление в виртуально-онлайновом информационном обществе. В основе исследования - конщептуализация базовых схем симулякров и виртуально-онлайновой культуры информационного общества, что и представляет собой научную новизну. Постановка задания - использование подходов, в частности структурно-синергетичской и практически-синергетической методологии, которая дает возмрожности проанализировать симулякры постмодерна как сложные конструкции. Изложение основного материала. Осуществлен анализ становления и развития онлайново-виртуальной культуры личности, которая пользуется симулякрами; представлено определение «симулякр»; осущетслвен анализ того, что игровая составляющая становится составной доминантой современного виртуального мира, а сама игра становится маркером постмодернистского общества, в центре которого перфомативное, игровое «Я»; представлено определение «онлайнововиртуальной» культуры, в контексте которой реализуется «Я»; проанализировано, что представляет собой сетевой соииум как новый вид культуры (субкультуры) виртуальной реальности. Выводы - сформирована концепџия симулякров виртуально-онлайновой культуры информационного общества в конщептуальных измерениях постмодернистов.

Ключевые слова: симулякр, виртуально-онлайновая культура, информационное общество, постмодерн, игровая составляющая виртуального мира, игровое «Я».

Стаття рекомендована до публікачї̈ д.філософ.н., проф. О. П. Пунченко (Одеса, Україна) Надійшла до редколегіï: 10.06.2018 Прийнята до друку: 15.06.2018 